\title{
OS OUVIDORES E A CÂMARA MUNICIPAL DA VILA DE CURITIBA: UMA AMOSTRAGEM DA CIRCULARIDADE DA CULTURA JURÍDICA NA AMÉRICA PORTUGUESA (1721-1750)
}

\section{OUVIDORES E LA CÂMARA MUNICIPALE DI CURITIBA: UN CAMPIONE DELLA CIRCOLARITÀ DELLA CULTURA GIURIDICA NELLA AMERICA PORTOGHESE (1721-1750)}

\author{
${ }^{1}$ Vanessa Caroline Massuchetto
}

\section{RESUMO}

O presente estudo busca expor a análise da circularidade da cultura letrada nas localidades coloniais do Império Ultramarino Português através de um organismo específico: a Ouvidoria de Comarca. O espaço analisado nessa relação de trocas é o Conselho Camarário Municipal, que constitui o objeto de fiscalização e local de atuação dos ouvidores gerais de Comarca nos termos da estruturação institucional da sociedade portuguesa de Antigo Regime. O foco é compreender, mesmo que de modo breve, a dinâmica da recepção da cultura letrada nas vilas americanas sob domínio português a partir da atuação de um oficial letrado (formado, portanto, na metrópole) enviado ao ultramar com objetivos de manutenção da padronização político-jurídico-administrativa ao longo do Império. A pesquisa pretendeu observar principalmente quais são as formas de transmissão da cultura metropolitana deste oficial ao mesmo tempo em que recepciona e auxilia na conformação de elementos próprios da cultura local. Para tal visualização, foram selecionadas fontes locais de Curitiba, concentrando-se nos ouvidores que fizeram parte da Ouvidoria da Comarca de Paranaguá e na Câmara da Vila de Nossa Senhora da Luz dos Pinhais de Curitiba, passando pelo período de 1721 a 1750.

Palavras-chave: Antigo regime português, América portuguesa, Câmara municipal da vila de curitiba, Ouvidoria da comarca de paranaguá

\footnotetext{
${ }^{1}$ Doutoranda em Direito na Universidade Federal do Paraná, UFPR, Curitiba - PR (Brasil).

E-mail: vanessa.massuchetto@gmail.com
} 


\section{RÉSUMÉ}

Questo studio si propone all'analisi di circolarità della cultura metropolitana nelle città coloniali dell'Impero d'Oltremare Portoghese attraverso un organo specifico: il Ouvidor della Comarca. Lo spazio indagato in quente relazioni di scambio culturale è il consiglio municipale, che è l'oggetto di ispezione e luogo di esecuzione delle atribuizioni dei ouvidores della comarca nella struttura istituzionale della società portoghese delantico regime. L'obiettivo è comprendere, anche se per breve tempo, le dinamiche di ricevimento della cultura metropolitana in villaggi americani sotto il dominio portoghese dal lavoro di un funzionario laureato nella metropoli inviato all'otremare con i obiettivi di mantenimento del modello politico-giuridico-amministrativo in tutto l'Impero. La ricerca è destinata principalmente a osservare quale sono le modalità di trasmissione della cultura metropolitana di questo funzionario, allo stesso tempo in cui accoglie e assiste nella conformazione di elementi della cultura locale. Per questo, sono stati selezionati fonti locali di Curitiba, concentrandosi sui ouvidores che facevano parte di Paranagua e il Consiglio della Vila de Nossa Senhora dos Pinhais Curitiba, attraverso il periodo 1721-1750.

Mots-clés: Antico regime portoghese, America portoghese, Câmara municipale della vila di curitiba, Ouvidoria della comarca di paranagua 


\section{INTRODUÇÃO}

É fundamental, ao estudo do Antigo Regime na América do século XVIII, ter em mente as vicissitudes compreendidas neste tempo e neste espaço específicos, com observância à construção particular e o funcionamento do aparato jurídico-políticoadministrativo $^{1}$ português. É sedimentar ater-se a algumas das várias minúcias que circundam o tema, desde a ausência de um Estado moderno (excluindo-se de qualquer compreensão a noção de "Estado absolutista") configurado nos termo do entendimento da historiografia tradicional até a

relevância da montagem das relações de poder entre a metrópole e as periferias no Império

Ultramarino Português.

O sistema político pré-revolucionário não se funda numa lógica de poder centralizado e global, em que as unidades políticas prestam auxílio e participação na efetivação deste poderio. A ideia mais adequada para a representação desta espécie de estrutura é a da compatibilização dos organismos autônomos e a consequente não intervenção (nem imposição de condutas) de uns em outros. É esta a configuração da comunidade política, ligada à inviolabilidade dos direitos dos particulares - direito de atuação na política, concedido conforme a ordem jurídica tradicional - e à desvinculação entre poder e os regramentos surgidos e praticados nas periferias autônomas. Os mandos do "Estado",2 não representavam atos com força suprema e não vinculavam, segundo a mentalidade política do Antigo Regime, a alguma espécie de submissão obrigatória. ${ }^{3}$

\footnotetext{
1 PEREIRA, Luís F. L. Estruturas Político-Jurídicas Na América Portuguesa: Entre Centro E Periferia. In: Primer Encuentro Latino Americano de Historia del Derecho y la Justicia, 2009, Cidade do México. História del derecho y la justicia, 2009.

2 O termo "Estado" foi posto entre aspas para marcar a historicidade do próprio conceito.

3 HESPANHA, A. M.. Poder e Instituições na Europa do Antigo Regime. Lisboa: Fundação Calouste Gubenkian, 1994. p 40-41.
}

Revista Brasileira de História do Direito | e-ISSN: 2526-009X | Minas Gerais | v. 1 | n. 2 | p. 20 - 47 | Jul/Dez. 2015. 
Neste espectro, a estrutura através da qual se deu a montagem do Império Português se explica pela existência de uma concepção corporativa de sociedade ${ }^{4}$, embebida pela mentalidade de que a sociedade - os homens e as coisas - era governada por uma ordem universal que transportaria todos a um mesmo objetivo. Assim, cada segmento do corpo

social detinha sua importância ao funcionamento do organismo e o poder conferido "naturalmente" - a cada uma das esferas representava sua autonomia politico-jurídica necessária ao desempenho de suas funções ao todo. Portanto, nesse entendimento, a finalidade do poder político e a realização da justiça ocorriam segundo a representação da vontade da

ordem universal de, utilizando-se do conceito de equidade aristotélico, de dar a cada um o que é (de acordo com o direito natural) seu, tido como uma forma de prover "a manutenção da ordem social e política objectivamente estabelecida" 5 .

O Antigo Regime era, sob essa perspectiva, montado como uma sociedade de "estados" garantidores de privilégios que determinavam a qual estatuto o indivíduo estaria submetido. 6 Através dessa visão acerca do universo, "A pessoa deixa de corresponder a um substrato físico, passando a constituir o ente que o direito cria para a faceta, situação ou estado em que o indivíduo se lhe apresenta."7. Com isso, é possível que haja uma multiplicidade de "estados" que definiam quais relações sociais os indivíduos poderiam integrar e a quais capacidades estariam habilitados no que tange às funções no social.

Em meio a esse contexto, a tradição jurídica era, além das justiças reproduzidas pelas corporações, feita pelo ius commune, espécie de conjunto de regramentos que revelavam uma certa unidade do direito reproduzido na Europa ocidental. Essa característica de unidade, conforme Hespanha, emerge por unificar várias fontes do direito, constituir uma

\footnotetext{
4 HESPANHA, A. M.. O Direito dos Letrados no Império Português. Florianópolis: Fundação Boiteux, 2006. p 29.

5 HESPANHA, 2006, p 31.

6 Ibid., p 49-50.

7 Ibid., p. 48.
} 
conjunção única de regramentos, utilizar modos comuns de aplicação desse conjunto, embasado num ensino jurídico que era idêntico em toda a Europa ocidental (até a segunda metade do XVIII, período em que houve o inicio das políticas reformistas do reinado de Dom José I, a formação universitária em direito era fundamentada no direito romano e no direito canônico) e, por fim, por utilizar uma língua universal, o latim. Mas essa relativa unidade não seria coerente se tratasse de contextos sociais diversificados. Ou seja, a organização do Império, da religião e do direito nos países europeus detinha muitos aspectos semelhantes, na tendência de uma organização "natural" 8 da sociedade.

Figurando como a principal $^{9}$ rede formal deste contexto do direito comum, as Ordenações Filipinas (1603) eram um conjunto de regras jurídicas emanadas pelo aparato jurídico-político-administrativo do Império. Constituídas por um conjunto de normas (e cerceadas de costumes e demais estatutos jurídicos) que teriam derivado de um equilíbrio natural e uma ordem espontânea da natureza, as Ordenações basicamente delimitavam e regulavam as atribuições dos oficiais régios, não tendo foco, nem mesmo a pretensão, em

regrar as relações individuais, principalmente as sociedade-Estado ${ }^{10}$. O objetivo era deixar no formato escrito um conjunto de costumes comuns para a organização do Império, com a intenção de padronização das localidades em um modelo que se acreditava ser o melhor para o bem comum da sociedade. "Nessa perspectiva, e juridicamente, ao delegar poderes aos oficiais que nomeava, o rei procurava manter a paz e administrar o 'bem viver' em comunidade." 11

Em que pese ajustar a manutenção da organização administrativa, as Ordenações não tinham a intenção de incorrer numa totalização, isto é, de regulação minuciosa de todo o aparelho administrativo. O ideal era que se cumprissem os padrões

\footnotetext{
8 A noção de "natural" neste ponto utilizada relaciona-se com a natureza, ordem natural em conformidade à natureza das coisas.

9 As Ordenações Filipinas são as principais normas formais, porém não as únicas. Existiam legislações "extravagantes", além dos provimentos régios e demais fontes do direito.

10 SALGADO, G. Fiscais e meirinhos: a administração no Brasil colonial. Rio de Janeiro: Nova Fronteira, 1985. p 15-16.

11 PEGORARO, J. W.. Ouvidores régios e centralização jurídico-administrativa na América portuguesa: a Comarca de Paranaguá (1723-1812), Curitiba, 2007, Dissertação (Mestrado em História) - Setor de Ciências Humanas, Letras e Artes, Universidade Federal do Paraná, p 13.
}

Revista Brasileira de História do Direito | e-ISSN: 2526-009X | Minas Gerais | v. 1 | n. 2 | p. 20 - 47 | Jul/Dez. 2015. 
estabelecidos, mas a flexibilização estava com frequência presente. Portanto, era comum a convivência entre aqueles modelos, as modificações ou ampliações postas pelos provimentos régios - cujas normas igualmente não eram acompanhadas pela rigidez - e a emergência de diferentes características em virtude do casos específicos.

No que toca à relação entre a metrópole e os domínios do Império Ultramarino inseridos na lógica supracitada, cabe destacar que a perspectiva tomada pelo presente trabalho segue a linha que tem sido produzida pela historiografia recente - que tem como maiores nomes António Manuel Hespanha, João Fragoso, Maria Fernanda Bicalho, Maria de Fátima Gouvêa -, isto é, sem fundamentá-la a partir do viés centralizaçãodescentralização. É cediço que este formato de relações centro-periferia, clássico para a explicação dos fenômenos havidos na América Portuguesa, "não é mais suficiente para explicar a complexidade das redes e conexões que ligaram os diferentes domínios ultramarinos, entre si e com o centro da monarquia" 12 . O conceito de Império Marítimo Português, empregado pela primeira vez por Charles Boxer ${ }^{13}$, emerge na tentativa de se compreender o - amplo e plural - complexo conjunto de relações havidas na dinâmica ultramarina portuguesa abarcando a lógica das redes imperiais, inter-relações tecidas entre as colônias portuguesas por meio da circulação de oficiais régios, trocas comerciais e, para além, trocas de aspectos culturais, de forma a conectar as pontas do império ultramarino ao centro e manter tanto a flexibilidade quanto a rigidez desse "sistema" 14 O entendimento deste espectro traz à tona a evidência da porosidade do "sistema" como um todo, era o que lhe conferia equilíbrio, possibilitando que essa situação perdurasse até a primeira metade do século XIX ${ }^{15}$.

Exposta a dinâmica imperial portuguesa, o foco privilegiado do presente trabalho se dá à "convivência e o choque de culturas"16 através da atuação da figura do

\footnotetext{
12 BICALHO, M. F. B.. Da colônia ao império: um percurso historiográfico. In: BICALHO, M. F.; FURTADO, J. F.; SOUZA, L. de M. e (orgs.). O governo dos povos. São Paulo: Alameda, 2009. p 91.

13 BOXER, C.. O Império Marítimo Português: 1415-1825. São Paulo: Companhia das Letras, 2008.

14 A palavra "sistema" vem entre aspas porque não se deve compreendê-la neste contexto como algo fechado e coeso (nos termos do entendimento moderno da palavra), mas sim como conjunto de elementos interconectados, que não necessariamente detêm coerência entre si e não estão fechados às influências externas.

15 BICALHO, 2009, p. 105.

16 GINZBURG, C.. Relações de força: história, retória, prova. São Paulo: Companhia das Letras, p 14.
} 
Ouvidor da Comarca de Paranaguá na Vila de Curitiba. Nesse sentido, o jurídico é compreendido a partir de sua dimensão cultural, ou seja, é encarado não como somente leis e regramentos advindos de um ente estatal, mas sim como signos e representações com dimensão normativa componentes da cultura, aqui compreendidos os costumes, a religião, a moral, que detém um caráter fluído dentro das relações sociais. ${ }^{17}$ O jurídico compreendido como componente da cultura de uma determinada localidade é dotado de circularidade, como um elemento que participa das trocas realizadas entre sociedades, entre personagens.

Quanto à estratégia metodológica, a adotada neste trabalho é o método indiciário, engenhado por Carlo Ginzburg ${ }^{18}$. O estudo é guiado a partir da coleta de rastros, pistas, vestígios da perspectiva particular, com documentos que dizem respeito à micro-história, para, então, a partir de elementos do local tentar enxergar um espectro um pouco maior. Isto é, o olhar ao particular e a atenção voltada àquilo que foge à regra e constitui-se como vicissitude local (no espaço micro das relações da Ouvidoria de Paranaguá para com a Câmara da Vila de Curitiba) possibilitam a compreensão dos funcionamentos também dos elementos e estruturas gerais, quais sejam, das relações das Ouvidorias no Império Ultramarino Português na América Portuguesa. É nesse sentido que pinçando as exceções se encontram as regras.

\section{A ADMINISTRAÇÃO DA JUSTIÇA NO IMPÉRIO ULTRAMARINO PORTUGUÊS}

Para a compreensão do cerne da atuação dos aparatos político-jurídicoadministrativos do Império Português, é importante destacar que a municipalidade foi, sobretudo no período da consolidação dos domínios portugueses, a base estrutural da colonização. Os conselhos locais, que segundo Rosângela Maria Ferreira dos Santos

17 PEREIRA, L. F. L.. A circularidade da cultura jurídica: notas sobre o conceito e sobre o método. In: FONSECA, R. M.(org.). Nova História do Direito Brasileira. Ferramentas e Artesanias. Curitiba: Juruá, 2012.

18 GINZBURG, C.. A micro-história; e outros ensaios. Lisboa: Difel, 1989. 
e António Cesar de Almeida Santos ${ }^{19}$ tiveram como modelo a priori a lógica romana e foram, seguindo a perspectiva de Stuart $\mathrm{Schwartz}^{20}$, as principais estruturas do aparelho judicial e administrativo português em toda a extensão do Império. Neste mesmo sentido, ainda, Nuno Gonçalo Monteiro ${ }^{21}$ expõe que, pelo menos até finais da configuração do Antigo Regime político (isto é, fins do XVIII e início do XIX) português, as câmaras municipais, a nível local, representam um poderio muito semelhante que o das cortes a nível metropolitano, o que abre espaço à afirmação de que eram detentoras de uma autonomia local.

Os municípios surgiram nas comunidades locais portuguesas pela finalidade de proteção através do estabelecimento de uma ordem interna própria, engenhada inclusive com sistemas de direito e justiça. Buscando uma espécie de extensão do poder central, o rei estabeleceu forais com esses conselhos, passou a manter "forças militares e serviços" nas localidades, de forma a tornar seu reino legítimo naquele locus. Nessa perspectiva, os municípios foram se tornando organismos estruturais ao Império, visto que detinham função benéfica tanto ao centro do Império quanto aos organismos locais: ao mesmo tempo em que mantinha simbolicamente o braço real na localidade (fazendo com que os súditos das mais afastadas regiões cultivassem a devoção ao rei), assegurava a autonomia nas decisões locais.

$\mathrm{Na}$ formulação das Ordenações (tanto nas Afonsinas, de 1446, quanto nas Manuelinas, de 1521 e nas já citadas Filipinas), considerou-se estabelecer formalmente a estrutura dos municípios, bem como suas competências, atribuições - de ordem administrativa, judicial, fazendária e policiais - e forma de preenchimento dos seus ofícios, com aquela pretensão de estabelecer um padrão a todo o

\footnotetext{
19 SANTOS, R. M. F. dos; SANTOS, A. C. de A.. Eleitores e eleições no Brasil Colonial (Curitiba, 1749-1827). In: SANTOS, R. M. F. dos; SANTOS, A. C. de A. (orgs). Eleições da Câmara Municipal de Curitiba (1748 a 1827). Curitiba: Aos Quatro Ventos, 2003.

20 SCHWARTZ, S. B. Burocracia e Sociedade no Brasil Colonial: o Tribunal Superior da Bahia e seus desembargadores, 16091751. São Paulo: Companhia das Letras, 2011. p 30-32.

21 MONTEIRO, N. G. F. Os concelhos e as comunidades. In: MATTOSO, J. (dir.); HESPANHA, A. M. (coord.). História de Portugal Vol. IV - O Antigo Regime (1620-1807). Lisboa: Editorial Estampa, 1998. p. 269.
} 
Império. $^{22}$ Todavia, muitas instituições fugiam dessa regra em razão da diversificação entre os locais em que estavam estabelecidas, tanto em tamanho territorial quanto na cultura, nos costumes e tradições. Mas, por ser o mesmo regramento a todo o Império, as configurações não possuíam diferenças muito salientes.A composição do conselho era normalmente feita com os cargos de juiz ${ }^{23}$, vereador e procurador, podendo haver outros cargos como corregedor (magistrado), tabelião, escrivão, contador, distribuidor, inquiridor, notário, avindor (espécie de conciliador), carcereiro e oficiais menores, sendo comum que mais de um ofício fosse exercido pela mesma pessoa. ${ }^{24}$ As atribuições judiciais camarárias versavam, em suma, sobre a primeira instância judicial com competência de julgamento à maioria das matérias.

Ao juiz ordinário cabia, a grosso modo, a administração da justiça e a manutenção da ordem ${ }^{25}$. Este oficial, principalmente na primeira metade do XVIII (período anterior às tentativas josefinas de reforma da justiça), representava a principal autoridade dentro do conselho da municipalidade. Não era necessário que tivesse formação letrada e a eleição ao cargo se dava por votos da comunidade local. A ausência de "formação letrada" refere-se à simples falta do bacharelado em direito, o que não remete a esses oficiais a característica necessária e indissociável da rusticidade. Isso porque, embora desprovidos da formação teórica, consoante defende Luís Fernando Lopes Pereira, o exercício prático usualmente fornecia aos oficiais conselhios modos de apreensão das técnicas da instituição. Ou seja, em que pese não detivessem características de "letrados"26, não significa que seriam ignorantes, rústicos ou, até mesmo, analfabetos.

\footnotetext{
22 SANTOS; SANTOS, 2003. p 6-8.

23 Principalmente juízes ordinários, de fora, de órfãos - em "terras com mais de 400 vizinhos" se nomeava um juiz exclusivo de órfãos; em locais com menor população, a função era conferida ao juiz ordinário.

(HESPAnhA, A. M.. Âs vésperas do Leviathan: Instituições e Poder Político - Portugal - séc. XVII. Coimbra: Livraria Almedina, 1994, p 180).

24 Id.

25 ORDENAÇÕES FILIPINAS, Livro I, Título LXV.

26 Saliente-se que a expressão "letrado" é utilizada ao longo da exposição deste trabalho como sinônimo de bacharelado. Na tentativa de colocar de lado a carga simbólica e pejorativa, utilizar-se-á com maior frequência as expressões "bacharelado" e "formação em direito".
} 
Estes oficiais tinham as atribuições estabelecidas nas Ordenações, recebiam mandos régios e eram fiscalizados pelos Ouvidores, no entanto existiam diversas "aberturas" às suas formas de atuação. Para além, com a ausência da compreensão do absolutismo jurídico, pode- se afirmar que na prática, portanto, a câmara deteve um amplo espaço de autonomia, exercida através dos julgamentos em processos vinculados ao juízo ordinário do conselho e, ainda, por meio das Posturas Municipais.

Estas Posturas eram regulamentos elaborados pelos membros da câmara sobre questões locais no que tange à convivência dos citadinos nos ambientes em comum, como comportamentos, civilidade, urbanismo, salubridade, arquitetura, abastecimento entre outros a serem cumpridas pelos habitantes e pelos conselhos. Inicialmente eram orais, mas a partir do século XV houve obrigatoriedade, pelo disposto nas Ordenações Afonsinas, que fossem registradas em um livro específico. Conforme Magnus Roberto de Mello Pereira, essas Posturas mantiveram até pelo menos o século XVIII traços marcantes de direito consuetudinário próprio do Antigo Regime. Ou seja, representavam além de um espaço de autonomia municipal, um âmbito de pacto simbólico com próprio o rei, já que eram normas que não poderiam ser alteradas por autoridades régias, apenas de forma direta pelo rei através de recursos. ${ }^{27}$

Hierarquicamente acima da Câmara Municipal, estava a Ouvidoria de Comarca, figurando como o organismo fiscalizador direto dos conselhos do Império Ultramarino. Num primeiro momento da colonização eram oficiais senhoriais, ou seja, ligados à capitania para a fiscalização do território e para tanto recebiam doações dos capitães donatários da coroa - faziam parte, portanto, de Ouvidorias de Capitania. Posteriormente, foram atraídos à administração como instituição do aparato imperial, integrando a Ouvidoria de Comarca. 28

\footnotetext{
27 PEREIRA, M. R. de M.; SANTOS, A. C. de A.. Códigos de Posturas Municipais. In: PEREIRA, M. R. de M. (org.). Posturas municipais - Paraná, 1829 a 1895. Curitiba: Aos Quatro Ventos, 2003, p 4-6.

28 HESPANHA, 1994, p 192-193.
} 
Acima das Ouvidorias de Comarca estavam as Ouvidorias-Gerais de Capitania. Estas faziam parte da estruturação básica de todos os domínios imperiais, prova disso é o fato de que ao início da colonização da América Portuguesa foram criadas três ouvidorias gerais que, independentes entre si e com jurisdições lançadas sobre territórios diferentes, abarcavam a totalidade das possessões portuguesas. Assim, a Ouvidoria-Geral do Estado do Brasil, em 1549, a Ouvidoria-Geral da Repartição do Sul, em 1608, e a Ouvidoria-Geral do Estado do Maranhão, em 1619, representaram a estrutura principal da administração da justiça na América Portuguesa ao longo do século XVII. ${ }^{29}$

Conforme definido pelas Ordenações, os ouvidores, no organismo jurídico-políticoadministrativo exerciam funções em posição hierárquica superior aos juízes e inferior aos Tribunais da Relação (onde estavam alocados os desembargadores) - com encargos jurisdicionais intermediários entre estes organismos. As atribuições, a priori, versavam acerca do conhecimento de recursos interpostos sobre as decisões dos juízos locais. 30

Em que pese em Portugal os ofícios de ouvidor e corregedor sejam institutos com atribuições e jurisdições diferentes, na América Portuguesa aquele detinha poderes em muito semelhantes aos do corregedor. O local de atuação dos corregedores era a comarca, mas na atuação do Império na colônia, as atribuições foram gradativamente imantadas pelos ouvidores, exercidas na jurisdição de uma comarca (que englobava várias vilas e estava vinculada, assim como outras comarcas, a uma capitania régia). ${ }^{31}$

\footnotetext{
29 MELLO, I. de M. P. de. Os ministros da justiça na América Portuguesa: ouvidores-gerais e juízes de fora na administração colonial (sec. XVIII). Revista de História, São Paulo, n 171, p 351-381, 2014.

30 ORDENAÇÕES FILIPINAS, Livro I, Título LIX e Título LVIII.

31 PEGORARO, 2007. p 24.
} 
Os corregedores, segundo o definido pelas Ordenações $^{32}$, eram "magistrados ordinários nomeados da real administração periférica"33 . Nomeados pelo rei, detinham responsabilidade por encargos jurídicos, políticos e de administração. Em forma de tutela aos órgãos de administração política e jurídica, as funções do corregedor - e, na América Portuguesa, dos ouvidores - eram de tal forma gerais ${ }^{34}$, inclusive a nível de comarca, o que "faz com que seja em geral neles que confluam as atribuições da administração real periférica não previstas nas Ordenações. „35

A nível de capitania, os oficiais camarários estavam ligados, e subordinados hierarquicamente, aos governadores. Estes eram, num primeiro momento da colônia, os donatários da coroa, portugueses que receberam por meio das doações parcelas de território para geri-lo da melhor forma, no entanto sem afastar-se dos desejos régios. Após foram nomeados governadores e o rei lhes atribuiu competência para de fato governar as comarcas e vilas sob jurisdição da capitania.

\footnotetext{
32 ORDENAÇÕES FILIPINAS, Livro I, Título LVIII, itens 21 a 30.

33 PEGORARO, 2007, p 201.

34 ORDENAÇÕES FILIPINAS, Livro I, Títulos VII, VIII, LVI, LVIII.

35 PEGORARO, Op. cit., p 201.
} 


\section{A CIRCULARIDAdE DA CULTURA JURÍDiCA LETRADA POR PARTE DOS OUVIDORES À CÂMARA DE CURITIBA: UMA AMOSTRAGEM DAS RELAÇÕES NO IMPÉRIO PORTUGUÊS}

A perspectiva metodológica de Carlo Ginzburg orienta que a atenção, no momento do estudo de culturas de tempos passados, deve estar centrada na identificação das sutilezas, dos detalhes e das minúcias, visto que é através destas que se torna possível decifrar esta

realidade opaca. ${ }^{36}$ Ainda, a análise em zonas privilegiadas permite a apreensão das anomalias, das condutas que fugiam à regra, fatores que trazem à tona não somente a exceção à regra, por assim o constituírem dentro de uma determinada sociedade, bem como a regra em si. Assim, o objetivo do enfoque à Vila de Nossa Senhora da Luz dos Pinhais de Curitiba se dá, para além da disponibilidade e facilidade do manejo de fontes, mas sobretudo porque esse locus fornece uma visão privilegiada das relações havidas no interior do Império Ultramarino. Isso porque configurava-se um território bastante periférico da América Portuguesa além de se localizar em um ponto geográfico que destoa da grande maioria escolhida pela estratégia

do Império Ultramarino: não é localizada em área marítima (saliente-se, inclusive, que encontra-se em um planalto de difícil acesso). Ou seja, em razão destas características particulares, a Vila de Curitiba torna-se bastante significativa para a compreensão do funcionamento das redes de poder existentes no Antigo Regime Português. Nesse sentido, as fontes documentais utilizadas para o embasamento da presente análise são os provimentos de correições realizados pelos ouvidores da Comarca de Paranaguá à Vila de Curitiba entre os anos de 1721 a 1750, constantes no Boletim do Archivo Municipal de Curytiba (BAMC), transcritos e compilados por Francisco Negrão. Salientase, ainda, que a opção do presente trabalho quanto à grafia na transcrição de trechos dos documentos foi a atualização ortográfica sempre que não prejudique o sentido.

36 GINZBURG, C.. Mitos, emblemas, sinais: morfologia e história. São Paulo: Companhia das Letras, 1989. p. 177. 
As origens do povoamento efetivo da região de Curitiba ocorreu sobretudo em meados do século XVII tendo como principal fator de atração as noticias de que havia ouro naqueles territórios. Na primeira metade, houve concessão de terras da região a título de sesmarias e a instalação de pequenos povoados, sendo a tomada de posse, com elevação do povoado à condição de vila e levantamento do pelourinho por Gabriel de Lara $^{37}$ em nome de Marquês de Cascais - donatário de quase a integralidade das terras meridionais da América Portuguesa -, realizada apenas em 4 de novembro de 1668. Em 1693, a requerimento dos moradores do povoado, houve a eleição do Conselho Municipal da Vila de Curitiba e a criação das justiças, sendo assim que o povoado passa à condição de Vila a partir de um instrumento jurídico, a petição dos povos. 38

Criada a Vila de Nossa Senhora da Luz dos Pinhais de Curitiba nos seiscentos, ao início do século seguinte, em 1711, foi comprada pelo rei e então incorporada ao Império Português. Nesse caminhar, obteve crescimento urbano, além de mudanças nas formas de atuação camarária. Ou seja, foi ao longo do XVIII que a Câmara foi, gradativamente, tomando forma de organismo político-jurídico-administrativo. Insta salientar o caráter paulatino, mesmo porque, na linha do sustentado por Magnus Pereira, até os setecentos as atribuições camarárias não eram voltadas à realização de serviços "públicos"39 à população da Vila, tanto que sua estrutura não fora preparada para tanto. 40

Curitiba é representativa de uma grande parcela das localidades brasileiras, para as quais o século XVIII foi um período de relativo crescimento urbano. Se, nos séculos anteriores, a ênfase de muitas câmaras recaia sobre a mediação política, no XVIII ela passa a concentrar-se no administrativo. ${ }^{41}$

\footnotetext{
37 "A lacuna de poder é ocupada pela figura ambígua de Gabriel de Lara que atuou tanto como representante do conde da Ilha do Príncipe, como governador em nome do marques de Caiscais ou como agente da coroa portuguesa." (NICOLAZZI JR., N. F.. O almotacé na Curitiba colonial (1718-1828). In: PEREIRA, M. R. de M.; NICOLAZZI JR., N. F. (orgs.). Audiências e correições dos almotacés (Curitiba, 1737 a 1828). Curitiba: Aos Quatro Ventos, 2003. p 32-33).

38 PEREIRA, L.F.L. O Império Português: a centralidade do concelho e da cidade, espaço da cultura jurídica. In: FONSECA, R. M. (org.). As Formas do Direito. Ordem, Razão e Decisão (Experiências Jurídicas Antes e Depois da Modernidade). Curitiba: Juruá, 2013. p 1819.

39 O termo encontra-se entre aspas para marcar a historicidade do conceito.

40 PEREIRA, M.; SANTOS, 2003. p 37.

41 PEREIRA, M.; SANTOS, 2003. p 37.
} 
A respeito do viés da administração da justiça, em que pese muitos pesquisadores entenderem que nos anos subsequentes à eleição do primeiro conselho municipal os oficiais exerceram funções político-jurídico-administrativas de modo totalmente "rústico", isto é, sem acesso aos regramentos padronizadores das Ordenações bem como sem atenção aos registros que deveriam realizar de cada ato da Câmara e exercício de atribuições somente através da oralidade, tal interpretação revela-se, se não incorreta, ao menos bastante incompleta. A análise histórica deste particular que segue pela via da crença na ausência de reprodução de justiça formalizada nesse locus colonial revela-se um tanto simplista.

Nos termos da documentação mantida no acervo do Arquivo Público do Estado do Paraná, existem processos judiciais formalizados desde pelo menos $1711^{42}$, o que evidencia que as características da oralidade, do caráter "rústico" (de oficiais leigos) e da aplicação isolada dos costumes e tradições locais, conforme menção supra, não ocorreram exatamente nos termos do que alguns pesquisadores mencionam. Luís Fernando Lopes Pereira tece críticas a essa crença na rusticidade dos oficiais conselhios de Curitiba por existirem fontes históricas que demonstram alto grau de tecnicidade reproduzida nos atos institucionais. Por mais que desprovidos, num primeiro momento, do conhecimento técnico letrado, "vão a eles se familiarizando com o tempo, aprendendo a manejar as técnicas e a respeitar os procedimentos da esfera judicial que se montava nas Câmaras."43

Ainda, no mesmo sentido, Pereira expõe que, entre os documentos atinentes às receitas e despesas da Câmara Municipal de Curitiba compilados no Boletim do Archivo Municipal de Curytiba, identificam-se pagamentos realizados em razão da compra das Ordenações régias em 1704, bem como entre 1706 e 1709, o que comprova o contato dos oficiais com as regras formais do Império em período anterior à compra do território em que estava localizada a Vila pela Coroa portuguesa. 44

\footnotetext{
42 Conforme, a título de exemplo, o Inventário de Manoel Alves Pedroso, BR PRAPPR PB045 PC05.1, datado de 24 de agosto de 1711. Informações disponíveis em: http://www.arquivopublico.pr.gov.br/modules/conteudo/conteudo.php?conteudo=93. No mesmo sentido, Daniele Wobeto de Araújo expõe que os documentos históricos comprovam a formalização de processos judiciais desde 1715. Conforme: ARAÚJO, Danielle Regina Wobeto de. A Almotaçaria e o direito na Vila de Curitiba (1737-1828), Curitiba, 2011, Dissertação (Mestrado em Direito) - Setor de Ciências Jurídicas, Universidade Federal do Paraná, p 145.

43 PEREIRA, L., 2013, p 15.

44 PEREIRA, L., 2013, p 21.
}

Revista Brasileira de História do Direito | e-ISSN: 2526-009X | Minas Gerais | v. 1 | n. 2 | p. 20 - 47 | Jul/Dez. 2015. 
1704

Descarga dos gastos que faz o procurador Manuel Soares este ano de mil setecentos e quatro anos por mandado de todos os oficiais desta Câmara, por nove mil reis que deu a Andre Machado para trazer uma ordenação p. ${ }^{a}$ esta Câmara pois estava sem ela. . . $9 \$ 000(\ldots)^{45}$

É salutar que seja ressaltada a importância do que as fontes documentais da Câmara Municipal de Curitiba para contradizer a crença, muito dissipada, de que a aproximação dos oficiais da Vila para com o direito régio, e a burocratização própria dos aparatos administrativos imperiais portugueses, teria vindo tão somente com a correição do Ouvidor da Capitania de São Paulo, Raphael Pires Pardinho, em 1721.

Embora não se possa defender que os provimentos de correição deixados pelo Ouvidor Pardinho são o primeiro contato dos oficiais camarários da Vila de Curitiba com os regramentos do Império Português, reconhece-se a importância desta correição, visto que "foram elementos centrais na difusão dos procedimentos cabíveis às Câmaras e regulamentados pelas Ordenações."46 Para além, os mesmos provimentos foram repetidos em seu conteúdo até o século XIX, quando ocorreu a mudança nos organismos de administração jurídico-política pela legislação imperial. ${ }^{47}$

Estas indicações de como deveriam ser exercidas as funções e como deveriam se dar as aplicações dos regramentos imperiais são normalmente interpretados como uma "tradução" da linguagem tecnicista a cargo do Ouvidor aos oficiais locais, no intuito de prover a compreensão dos escritos formais. ${ }^{48}$ Concorda-se que, por esta ter sido a primeira correição realizada nos territórios ao sul da colônia, o Ouvidor tenha se deparado com atribuições que julgou serem exercitadas de maneira errônea ${ }^{49}$. Entretanto, isto não permite concluir que os oficiais atuassem de modos diversos àqueles desejados pela coroa por ausência de conhecimento do que seria o padrão. As fontes documentais

\footnotetext{
45 BOLETIM DO ARCHIVO MUNICIPAL DE CURYTIBA. Documentos para a História do Paraná. Sob a direcção de Francisco Negrão. Curitiba: Impressora Paranaense. v. VI, p. 40.

46 PEREIRA, L., Op. cit., p 21.

47 SAntos, Antonio Cesar de Almeida (org.). Monumenta. Provimentos do ouvidor Pardinho para Curitiba e Paranaguá (1721). vol. 3. n. 10. Curitiba: Aos Quatro Ventos, 2000. p 1.

48 BORGES, Joacir Navarro. Das Justiças e dos Litígios; A ação judiciária da Câmara de Curitiba no sécul o XVIII (1731-1752). Curitiba, 2009, Tese (Doutorado em História) - Setor de Ciências Humanas, Letras e Artes, Universidade Federal do Paraná, p. 75-76.

49

BOLETIM

ARCHIVO

MUNICIPAL

DE

CURYTIBA,

VIII,

6.
} 
sugerem a interpretação contrária: existia em grande medida um esforço dos oficiais locais em seguir os padrões com que haviam tomado contato na manipulação das Ordenações, compradas em 1704, ao mesmo tempo em que há indícios de que estavam operantes as conformações locais, numa confluência entre a cultura letrada reinol e os costumes circulantes na localidade da Vila.

Raphael Pires Pardinho formou-se em direito em Coimbra e havia exercido, antes da vinda à colônia, os cargos de Juiz de Fora e do Crime na Vila de Algarve, entre 1702 e 1705, e em Lisboa, entre 1707 e 1715. Em 1717 foi nomeado Ouvidor Geral da Capitania de São Paulo e, após, Intendente em Minas Gerais, prestando serviços por 16 anos na América Portuguesa. Posteriormente, em 1743, foi nomeado membro do Conselho Ultramarino e, em 1754, Conselheiro de Sua Majestade.

É interessante notar que a partir de cargos menores, de atuação eminentemente local, o oficial português alçou carreira após passar pela colônia. Do ponto de vista dos sujeitos que serviam o aparato político-jurídico-administrativo imperial, a ida à colônia para o exercício de encargos significava grandes chances de acrescentamento e engrandecimento, o que significava, além de honras, o ganho de proventos doados pela coroa em remuneração de serviços. Se por um lado os governos nas conquistas eram quase sempre considerados um pesado sacrifício para quem os desempenhava (já que poderiam findar em desgraças de ordem pessoal - como a morte - e de ordem política no regresso a Portugal), por outro representava o meio mais rápido e certeiro para se conseguir a grandeza da casa e proventos da coroa. Observando, portanto, a trajetória de carreira traçada pelo oficial em questão, pode-se afirmar que fez parte do que Nuno Monteiro nomina de elite institucional, isto é, elites estruturadas em hierarquias próprias e que tinham desejo de alcançar signos de distinção definidos pela metrópole. ${ }^{50}$

\footnotetext{
50 MONTEIRO, Nuno Gonçalo. Trajetórias sociais e governo das conquistas: notas preliminares sobre os vice- reis e governadores-gerais do Brasil e da Índia nos séculos XVII e XVIII. In: FRAGOSO, João; BICALHO, Maria Fernanda. \& GOUVÊA, Maria de Fátima (orgs.). O Antigo Regime nos trópicos; a dinâmica imperial portuguesa (séculos XVI-XVIII). Rio de Janeiro: Civilização Brasileira, 2001, p 280281.
} 
Comparecendo à Vila de Curitiba e deixando Provimentos em 26 de janeiro de 1721, o Ouvidor deixou suas impressões comparativas ao restante das Vilas do Império em carta do Rei de Portugal ${ }^{51}$. Em várias passagens expressa que os oficiais camarários não realizavam determinadas atribuições de acordo com o que normalmente se fazia em outras vilas do Império, como, por exemplo, o costume de não se abrir devassa, ou nas que foram abertas não havia culpados "por malicia" dos juízes. Isto é, os membros camarários tinham conhecimento das atribuições no que tange ao processamento de crimes, mas talvez existissem interesses locais relacionados a determinadas causas que os fizessem acreditar ser mais vantajoso ou sem necessidade o seguimento dos regramentos conforme expostos nas Ordenações.

Nos provimentos feitos à Vila de Curitiba, demonstra, já ao início, a preocupação em deixar minuciosidades acerca do padrão havido no Império Português.

E sendo esta a primeira correição que tem havido nesta vila, lhes deixa com mais extensão estes capítulos, para que observando os evitem as desordens em que até agora alguns tropeçavam por ignorância, e os maliciosos, não tenham já a desculpa de ignorantes. (Esta é a primeira correição). 52

Em geral, pode-se afirmar que o objetivo dessas correições era manter uma coerência no tocante à organização (administrativa, judicial, política, urbanística, etc.) das vilas do Império português além de aproximar simbolicamente o poderio régio dos citadinos $^{53}$. A busca era por uma padronização, conforme os mandos régios, entre as vilas da jurisdição, principalmente no tangente às justiças e à administração, deixando suas provisões às câmaras municipais. O ouvidor Pardinho promoveu correições em toda sua jurisdição ao longo dos primeiros anos a partir da data em que tomou posse (em setembro de 1717) do cargo. Ou seja, não era uma preocupação neste momento o controle da vila com objetivos de centralização político-jurídico-administrativa na metrópole portuguesa, era muito mais uma atitude simbólica que intentava disseminar no sertão da América Portuguesa os costumes e regramentos cultivados como parte da cultura que acontecia em Portugal e nas vilas mais centrais da colônia.

\footnotetext{
51 Transcrita em MARCONDES, M.. Documentos para a história do Paraná (1ª série). Rio de Janeiro: Typographia do Annuario do Brasil. 1923. pp 18-26.

52 BOLETIM DO ARCHIVO MUNICIPAL DE CURYTIBA, v. VIII, p. 6.

53 ARAÚJO, 2011. p 150.
}

Revista Brasileira de História do Direito | e-ISSN: 2526-009X | Minas Gerais | v. 1 | n. 2 | p. 20 - 47 | Jul/Dez. 2015. 
Os provimentos de fato tratam de praticamente todas as perspectivas da vida citadina, sejam elas jurídicas, burocrático-administrativas, geográficas ou financeiras. Inclusive, foram definidas, também, a obrigatoriedade das festas católicas bem como o comparecimento dos oficiais e moradores aos eventos. ${ }^{54}$ Essa estruturação da sociedade corporativa de Antigo Regime muito ligada ao catolicismo representa, em grande medida, a vinculação às relações de pertencimento desses povoados ao Império Ultramarino Português. Isto é, a religiosidade estimula não só a presença simbólica do rei em todos os territórios de conquistas - já que a noção de sociedade corporativa trazia a ideia de que a ordenação natural das coisas era dada por Deus e a pessoa que receberia o dom máximo de toda essa sociedade era o rei-, estabelecia, ainda, uma linguagem comum construída administrativamente por uma monarquia pluricontinental: a disciplina social católica, o que conferia uma espécie de "uniformidade" ou "apadronamento" entre as localidades.

Em que pese cada local reproduzir costumes e práticas específicos, a dinâmica religiosa, numa espécie de disciplina social, conferia certa dinâmica social assemelhada em todo o império. Ou seja, a religião atua também como uma espécie de regramento de condutas sociais, gerando uma disciplina social muito semelhante entre as vilas e comarcas mais distantes. Não se exclui que a característica de autogoverno bem como as hierarquias sociais costumeiras traçam histórias sociais diferentes para cada região, mas pode-se afirmar que por mais diversas que sejam essas trajetórias têm determinados pontos de conexão. Conforme a perspectiva de João Fragoso e Roberto Guedes, "Aqui, não custa insistir na ideia de obediência, pois ela era capaz de exercer o papel dos mecanismos de controle (...). ${ }^{.55}$

Essa disciplina, em grande medida, era o que possibilitava ao mesmo tempo em que fosse mantida uma reverência e subordinação (simbólica e política) ao rei, confundidas com o temor a Deus, fossem exercidas, no âmbito da localidade camarária, o autogoverno como base dessa monarquia corporativa.

\footnotetext{
54 BOLETIM, Op. cit., p. 6-7.

55 FRAGOSO, João; GOUVÊA, Maria de Fátima (orgs.). O Brasil colonial. v 3 (1720-1821). Rio de Janeiro: Civilização Brasileira, 2014. p 14.
} 
Logo após as correições de Pardinho, em 1723, foi criada a Ouvidoria de Paranaguá (por Carta Régia de 17 de junho de 1723 a partir de proposta deste mesmo Ouvidor ${ }^{56}$ ), com a finalidade de retirar a competência da Ouvidoria de São Paulo pela parcela sulista da colônia. Assim, foi instituída a nova Ouvidoria com jurisdição sobre Curitiba, Paranaguá, Cananeia, Iguape, São Francisco e Laguna. A partir de então, e até o ano de 1812 - ano em que a sede da comarca foi transferida para Curitiba -, os ouvidores lotados na Comarca de Paranaguá passaram a deter a competência para promover correições anuais sobre a Câmara da Vila de Curitiba, apontando os aspectos que não estivessem de acordo com os mandos reais.

Em outubro de 1726, o Ouvidor Geral da Comarca de Paranaguá, Capitão Manuel de S. Payo, compareceu à Vila de Curitiba para correição e ao realizar diversas questões acerca de questões anteriormente tratadas pelo Ouvidor Pardinho, como se existia um cofre na Câmara em que o dinheiro dos órfãos era mantido com segurança e se questionar os oficiais camarários acerca da jurisdição da região obteve resposta unânime: “era da jurisdição real e pertencente a coroa." 57

Em reforço à noção de simbolismo de identificação com o rei da religião neste período difundida, pode-se demonstrar que não era exatamente desejo do Império a divisão do poderio concreto com a instituição da igreja, como se vê através deste questionamento do Ouvidor aos oficiais camarários: "E perguntados se havia nesta Vila ou seu termo clérigos regulares ou seculares revoltosos que impeçam as execuções de Sua Majestade que Deus guarde ou perturbem o sossego público para se dar conta ao dito senhor." 58

\footnotetext{
56 Conforme Francisco Negrão em BOLETIM DO ARCHIVO MUNICIPAL DE CURYTIBA, v. VIII, p 52.

${ }^{5}$ Ibid., p 51.

58 BOLETIM DO ARCHIVO MUNICIPAL DE CURYTIBA, v. VIII, p 52.
} 
Nos anos de 1727 a 1731 o escrivão Thome Pacheco e Abreu e nos anos de 1732 a 1735 o escrivão e tabelião Antonio Alvres Freire certificam a leitura de todos os provimentos do Ouvidor Pardinho aos oficiais do conselho municipal. ${ }^{59}$ Importante expressar que a partir deste momento, a documentação traz a cada ano a certificação de leituras de todos os provimentos anteriores registrados nos livros da Câmara realizadas pelo escrivão do conselho aos oficiais ao início de todos os anos (com a ausência apenas do ano de 1750). ${ }^{60}$

Em razão destas anotações, é possível constatar que os oficiais camarários trouxeram à prática local o costume padrão ao longo do Império. Assim, é possível identificar que mesmo que não fossem exatamente cumpridos todos os termos deixados pelo letrado Pardinho, ao menos os oficiais da vila demonstraram algum esforço em compreendê-los e, senão incorporá-los na prática cultural da localidade, ao menos relembrá-los todo o ano aos oficiais para que ao menos prestassem atenção em suas condutas. Acredita-se desta forma porque de outro modo dificilmente a prática da leitura dos provimentos teria sobrevivido por 9 anos sem a fiscalização de um Ouvidor (já que na documentação disponível não foram encontrados registros ou rastros de provimentos nestes períodos, somente as anotações das leituras dos provimentos supracitados pelos oficiais conselhios). Ou seja, se não os regulamentos da cultura letrada foram incorporados na cultura da vila, ao menos o sentimento de pertencimento ao Império, em conjunto com o simbolismo circulante da monarquia corporativa do Antigo Regime português, estavam bastante presentes na circulação de culturas a ponto de aderir às práticas da Vila de Curitiba.

\footnotetext{
59 Ibid., p 56-57.

${ }^{60}$ Existem registros de tais leituras realizadas em 1736, 1737 (Ibid., p 62), 1738, 1739 (Ibid., p 65), 1740, 1741, 1742, 1743 (Ibid., p 68-70), 1744 , 1745 (Ibid., p 7374), 1746 (Ibid., p 77), 1747, 1748, 1749 e 1751 (Ibid., p 79).
} 
Após, em 4 de dezembro de 1735, o Ouvidor Manoel dos Santos Lobatto apresenta correição à Vila em que reforça exatamente a aplicação dos provimentos do então desembargador Pardinho, por ser "a tão soberana praxe a sua jurisprudência" e "mu y conforme o direito"61. Esta última afirmação sugere que os provimentos tenham trazido, como já citado, elementos da cultura letrada aos costumes da vila, além de ser possível, a partir dela, pensar que existia dentre as atuações dos ouvidores aqueles que porventura expedissem provimentos que não fossem conforme o direito. Este dado é interessante não só por trazer à tona a existência e reprodução daquela pluralidade jurídica comentada ao início do presente trabalho, mas também por sugerir que até mesmo os ouvidores, oficiais letrados, expediam regramentos contrários ao direito do rei. E isto poderia acontecer, dentre várias suposições possíveis, pela cooptação de interesses para com as elites das localidades ou por encontrar-se em situações em muito diversas daquelas tratadas na metrópole, em que era exigida uma atitude imediata sem a possibilidade de consulta às autoridades superiores na colônia.

Este Ouvidor, ainda, definiu regras acerca do pagamento de vinténs ao Vigário da Paróquia de Curitiba para a desobriga da confissão, estabeleceu que a capela deveria ganhar novo forro, determinou que os oficiais da câmara mandassem alargar as estradas, retirar a mata que encobria as ruas e construir pontes no caminho de Curitiba até Morretes, antigo Cubatão. Por fim, estabeleceu que o escrivão da câmara deveria receber dez mil réis anualmente enquanto que o alcaide oito mil réis a título de emolumentos pelo cumprimento de seus cargos. ${ }^{62}$

\footnotetext{
${ }^{61}$ Ibid., p. 58.

62 BOLETIM DO ARCHIVO MUNICIPAL DE CURYTIBA, v. VIII, p 60-61.
} 
Entretanto, o mesmo Ouvidor retornou em nova correição em novembro de 1737 e

\begin{abstract}
Achou ele Doutor Ouvidor geral que os Juízes e mais oficiais da Câmara não davam cabal cumprimento aos Provimentos assim os que tinha deixado na ultima correição como em os mais antecedentes pelos ministros seus antecessores; pelo que $1^{\circ}$ Proveu que daqui em diante se lhe desse em tudo cumprimento pena de pagarem a cada um dos que tivessem servido em Câmara até a primeira correição que se fizer doze mil reis que o por aplicado para as despesas da dita Câmara pela presunção deles não ler 63 ditos Provimentos pois se faz crível que se os lesse os haviam de observar. 6
\end{abstract}

Por esta razão, deixou nesta ocasião mais 5 provimentos, sendo que o que mais nos chama atenção diz respeito a necessidade de apelação ou de agravo para a condenação por parte dos Almotacés. Diz o Ouvidor que estes "condenavam a seu Arbítrio"64 e que poderiam condenar somente até a quantia de dez tostões sem realizar apelação aos oficiais da Câmara.

Posteriormente, em correição realizada em dezembro de 1739, o Ouvidor Manoel dos Santos Lobato voltou a mencionar a necessidade de cumprimento dos mandos anteriores, porém apenas lançou novos provimentos com os mesmos conteúdos daqueles de 1735 a respeito do pagamento de vinténs ao vigário da vila e da necessidade de abertura dos caminhos de chegada à vila. A ausência de menção sobre a obrigatoriedade de realização de apelação ao conselho por parte do almotacé, na dependência do valor da condenação a algum citadino, permite concluir que este regramento havia sido incorporado na cultura jurídica local; se não integralmente, ao menos em medida parcial.

Em dezembro de 1743, o então Ouvidor Gaspar da Rocha Pereira chamou a atenção do conselho para a ausência de medidas de pesos e arrobas, mandando que se respeitassem os padrões do reino, e mencionou novamente a necessidade de abertura da estrada entre a Vila e Morretes. ${ }^{65}$ Ambos provimentos foram repetidos por seu sucessor, Ouvidor Manoel Tavares de Siqueira, em correição de março de $1745^{66}$, fator evidencia

63 Ibid., p 63.

64 Ibid., p 63.

65 BOLETIM DO ARCHIVO MUNICIPAL DE CURYTIBA, v. VIII, p 71-72.

66 Ibid., p 75-76. 
que a medição errônea dos produtos havidos nos mercados da vila era muito mais uma prática costumeira do que a ignorância dos oficiais, sobretudo do almotacé, na fiscalização dos pesos e medidas. Quanto à ausência de abertura e consertos do caminho entre a vila e o litoral da região, os conselheiros afirmam, na ocasião do retorno do Ouvidor Tavares em fevereiro de 1746, que "não parece que assenta em Boa Razão serem os moradores do Termo desta Vila obrigados a fazer o Caminho em distrito alheio"67. Desta forma, proveu que fosse realizada uma limitação nesta obrigatoriedade e encerrou a correição por não ter mais o que prover.

Esta última correição do período em estudo neste trabalho, em que pese não tratar de elementos que podem ser identificados como jurídico, deixa entrever a autonomia relativa detida pelos organismos locais da América Portuguesa. Isto é, a prática existente no Antigo Regime era da coexistência de interesses locais com a lei régia, sendo que - como se percebe do demonstrado pela fonte documental - os representantes deste direito metropolitano respeitavam a autonomia dotada pelos organismos coloniais locais. Nesse sentido, era mantida uma "interdependência entre os agentes e funções e a ambiguidade do direito praticado, em termos adequado aos interesses locais, mas profundamente efetivador da vontade do reinol."68

Assim, é salutar que não se feche os olhos para a existência de uma rede de relações interdependentes, característica que a historiografia mais atual vem reforçando: a autonomia relativa.

67 Ibid., p 78.

68 PEREIRA, L., 2009, p 6. 


\section{CONSIDERAÇÕES FINAIS}

Expostas estas ideias, é possível concluir que o diálogo travado a respeito da atuação dos ouvidores de Comarca na Vila de Curitiba é melhor compreendido através da leitura da circularidade da cultura jurídica ${ }^{69}$. Isto porque não se percebe, na leitura das fontes documentais, um desejo ou necessidade - supostamente imposta pela coroa de controle e regulamentação exata e rígida das afastadas vilas imperiais, mas sim de um trânsito de culturas com a finalidade muito mais aproximada do desejo de conhecimento do que se passava no restante do Império do que de controle das atuações e fatores a isto coligados.

Nesse sentido, muito mais do que imposição de leis, é possível sugerir que as configurações coloniais registradas pelos provimentos dos ouvidores trazem à tona a ideia, supra mencionada, dos padrões em diversos sentidos nos espaços de sociabilidade citadina, inclusive deixam expresso e trazem o conhecimento, ao menos uma noção simbólica, do que seria considerado e desejado como espaço da cidade no inicio do século XVIII para a coroa portuguesa. A intenção, arrisca-se, seria de melhor delimitação do reino partindo de uma padronização daquilo que posteriormente será definido como urbe, ou espaço urbano.

Ao tratar de praticamente todas as perspectivas da vida citadina, os regramentos e noções transmitidas à colônia - a respeito dos costumes que circulavam nos ambitos jurídico, burocrático-administrativo, de delimitação geográfico, de regulamentação de mercado e de eventos religiosos - o objetivo não seria excluir a característica de autogoverno das câmaras bem como as hierarquias sociais costumeiras traçam histórias sociais diferentes para cada região, mas pode-se afirmar que são estabelecidos diversos pontos de conexão entre uma cultura colonial - ou uma "baixa" cultura jurídica - e uma cultura metropolitana - ou uma "alta" cultura jurídica -, provendo a circularidade. Essa

69 PEREIRA, L., 2012, p 31-53. 
circularidade e interpenetração de culturas, em grande medida, auxiliou a manutenção de uma subordinação (simbólica e política) ao rei ao mesmo tempo em que permitia que fossem exercidas, no âmbito da localidade camarária, o autogoverno como base dessa monarquia corporativa.

Por fim, o fato de o Ouvidor Pardinho ter se tornado Conselheiro Ultramarino e Conselheiro de Sua Majestade pode sugerir que de algum modo a outra ponta dessa circularidade da cultura jurídica tenha sido completada, isto é, que algum elemento que teria visualizado ou aprendido com a prática na parte sul colônia americana tenha sido levado a uma alta instituição imperial.

\section{REFERÊNCIAS BIBLIOGRÁFICAS}

ARAÚJO, Danielle Regina Wobeto de. A Almotaçaria e o direito na Vila de Curitiba (1737-1828), Curitiba, 2011, Dissertação (Mestrado em Direito) - Setor de Ciencias Jurídicas, Universidade Federal do Paraná.

BICALHO, Maria Fernanda Baptista. Da colônia ao império: um percurso historiográfico. In: BICALHO, Maria Fernanda; FURTADO, Júnia Ferreira \& SOUZA, Laura de Mello e (orgs.). O governo dos povos. São Paulo: Alameda, 2009.

BOLETIM DO ARCHIVO MUNICIPAL DE CURYTIBA. Documentos para a História do Paraná. Sob a direcção de Francisco Negrão. Curitiba: Impressora Paranaense. v. VI e VIII.

BORGES, Joacir Navarro. Das Justiças e dos Litígios; A ação judiciária da Câmara de Curitiba no século XVIII (1731-1752). Curitiba, 2009, Tese (Doutorado em História) Setor de Ciências Humanas, Letras e Artes, Universidade Federal do Paraná.

BOXER, Charles. O Império Marítimo Português: 1415-1825. São Paulo: Companhia das Letras, 2008.

FRAGOSO, João (org.). O antigo regime nos trópicos; a dinâmica imperial portuguesa (séculos XVI - XVIII). Rio de Janeiro: Civilização Brasileira, 2001.

Janeiro:

; GOUVÊA, Maria de Fátima (orgs.). O Brasil colonial. v 3 (1720-1821). Rio de

Civilização Brasileira, 2014.

GINZBURG, Carlo. A micro-história; e outros ensaios. Lisboa: Difel, 1989. 
2014 .

Mitos, emblemas, sinais: morfologia e história. São Paulo: Companhia das Letras,

Relações de força: história, retória, prova. São Paulo, Companhia das Letras,

2002.

HESPANHA, António Manuel. A constituição do Império português. Revisão de alguns enviesamentos correntes. In: FRAGOSO, João (org.). $\mathrm{O}$ antigo regime nos trópicos; a dinâmica imperial portuguesa (séculos XVI - XVIII). Rio de Janeiro: Civilização Brasileira, 2001.

. Às vésperas do Leviathan: Instituições e Poder Político - Portugal - séc. XVII. Coimbra: Livraria Almedina, 1994.

Boiteux, 2005.

Cultura Jurídica Europeia: síntese de um milênio. Florianópolis: Fundação 2006

O Direito dos Letrados no Império Português. Florianópolis: Fundação Boiteux, Gubenkian, 1994.

Poder e Instituições na Europa do Antigo Regime. Lisboa: Fundação Calouste

MARCONDES, Moysés. Documentos para a história do Paraná (1 ${ }^{\mathbf{a}}$ série). Rio de Janeiro: Typographia do Annuario do Brasil. 1923.

MATTOSO, José (dir.) e HESPANHA, António Manuel (coord.). História de Portugal Vol. IV - O Antigo Regime (1620-1807). Lisboa: Editorial Estampa, 1998.

MONTEIRO, Nuno Gonçalves F. Os concelhos e as comunidades. In: MATTOSO, José (dir.) e HESPANHA, António Manuel (coord.). História de Portugal Vol. IV - O Antigo Regime (16201807). Lisboa: Editorial Estampa, 1998.

Trajetórias sociais e governo das conquistas: notas preliminares sobre os vice-reis e governadores-gerais do Brasil e da Índia nos séculos XVII e XVIII. In: FRAGOSO, João; BICALHO, Maria Fernanda. \& GOUVÊA, Maria de Fátima (orgs.). O Antigo Regime nos trópicos; a dinâmica imperial portuguesa (séculos XVI-XVIII). Rio de Janeiro: Civilização Brasileira, 2001.

NICOLAZZI JR., Norton Frehese. $O$ almotacé na Curitiba colonial (1718-1828). In: PEREIRA, Magnus Roberto de Mello \& NICOLAZZI JR., Norton Frehese (orgs.). Audiências e correições dos almotacés (Curitiba, 1737 a 1828). Curitiba: Aos Quatro Ventos, 2003.

ORDENAÇÕES FILIPINAS, Livro I, Títulos VII, VIII, LVI, LVIII, LIX, LXV. PEGORARO, Jonas Wilson. Ouvidores régios e centralização jurídico-administrativa na América portuguesa: a Comarca de Paranaguá (1723-1812). Curitiba, 2007, Dissertação 
(Mestrado em História) - Setor de Ciências Humanas, Letras e Artes, Universidade Federal do Paraná.

PEREIRA, Luís F. L. Estruturas Político-Jurídicas Na América Portuguesa: Entre Centro E Periferia. In: Primer Encuentro Latino Americano de Historia delDerecho y laJusticia, 2009, Cidade do México. Historia delderecho y lajusticia, 2009.

O Império Português: a centralidade do concelho e da cidade, espaço da cultura jurídica. In: FONSECA, R. M.. (Org.). As formas do direito, ordem, razão e decisão. Curitiba: Juruá, 2013.

- Súditos d'El Rey na América portuguesa: Monarquia corporativa, virtudes cristãs e ação judicial na Vila de Nossa Senhora da Luz dos Pinhais de Curitiba. In: Revista do Instituto Histórico e Geográfico Brasileiro, v. 452, p. 51-86, 2011.

PEREIRA, Magnus Roberto de Mello \& NICOLAZZI JR., Norton Frehese (orgs.). Audiências e correições dos almotacés (Curitiba, 1737 a 1828). Curitiba: Aos Quatro

Ventos, 2003.

; SANTOS, António Cesar de Almeida. Códigos de Posturas Municipais. In: PEREIRA, Magnus Roberto de Mello (org.). Posturas municipais - Paraná, 1829 a 1895. Curitiba: Aos Quatro Ventos, 2003.

SANTOS, Antonio Cesar de Almeida (org.). Monumenta. Provimentos do ouvidor Pardinho para Curitiba e Paranaguá (1721). vol. 3. n. 10. Curitiba: Aos Quatro Ventos, 2000 .

SANTOS, Rosângela Maria Ferreira dos \& SANTOS, António Cesar de Almeida. Eleitores e eleições no Brasil Colonial (Curitiba, 1749-1827). In: SANTOS, Rosângela Maria Ferreira dos \& SANTOS, António Cesar de Almeida (orgs). Eleições da Câmara Municipal de Curitiba (1748 a 1827). Curitiba: Aos Quatro Ventos, 2003.

SCHWARTZ, Stuart B. Burocracia e Sociedade no Brasil Colonial: o Tribunal Superior da Bahia e seus desembargadores, 1609-1751. São Paulo: Companhia das Letras, 2011.

SUBTIL, José. Governo e administração. In: MATTOSO, José (dir.) e HESPANHA, António Manuel (coord.). História de Portugal Vol. IV - O Antigo Regime (1620-1807). Lisboa: Editorial Estampa, 1998.

. Os Poderes do Centro. In: MATTOSO, José (dir.) e HESPANHA, António Manuel (coord.). História de Portugal Vol. IV - O Antigo Regime (1620-1807). Lisboa: Editorial Estampa, 1998. 